\title{
Improvement of The Competency of Physical Education Teachers at Elementary School in Assessing Student Learning Outcomes in Mijen District, Semarang City
}

\author{
Sulaiman $^{1}$, Tri Nurharsono ${ }^{2}$, Cahyo Yuwono ${ }^{3}$, Agung Wahyudi ${ }^{4}$ \\ \{sulaiman@mail.unnes.ac.id ${ }^{1}$, trinurharsono@mail.unnes.ac.id ${ }^{2,}$ cahyoyuwono@ mail.unnes.ac.id ${ }^{3}$ \} \\ Universitas Negeri Semarang, Central Java, Semarang, Indonesia ${ }^{1,2,3}$
}

\begin{abstract}
The 2013 curriculum emphasizes two important things: 1) scientific approach and 2) authentic assessment. Teachers of physical education, health, and sports at elementary school in Mijen District, Semarang City have difficulties and obstacles in evaluating student learning outcomes with authentic assessments. It is important to improve their competence in assessing student learning outcomes. This is an action research involving 35 teachers. The results of the training showed that from the pre-test data, an average score of 70 was obtained and the post-test results obtained an average score of 85 in the competency of assessing student learning outcomes. There was an increase in competence $15 \%$. Thus, the training and classroom action activities have exceeded 75. With the improvement in the post test results, teachers in Mijen District could apply variations in the assessment of student learning outcomes well in the learning process.
\end{abstract}

Keywords: improvement, competence, assessment, learning outcomes, physical education, health, and sports teacher.

\section{Introduction}

Professional teachers are professions that require expertise in carrying out their duties such as educating, teaching, guiding, training, training and studying students at the primary, and secondary education levels [1]. This happens by the Government Regulation of the Republic of Indonesia Number 19 of 2017 which states that teachers are professional educators with the main task of educating, teaching, guiding, training, training, assessing, and assessing students in early childhood education through formal education, basic education, and secondary education.

Physical education teachers in Elementary school according to Government Regulation Number 19 of 2005 concerning National Education Standards, should have competencies: pedagogical, personal competence, professional competence, and social competence. Pedagogic competence is the ability that teachers have in managing the teaching and learning process from the planning process to the learning outcome evaluation process which consists of teachers' understanding of 1) educational foundations, 2) characteristics of students, 3) curriculum development, 4) lesson plans, 5) implementation of educational learning, 6) utilization of informatics technology, 7) evaluation of learning outcomes, 9) evaluating the 
potential of students [1]. Meanwhile, [2] and [3]state that pedagogical competence is the ability of a teacher to manage the learning process, including student understanding, learning design and implementation, evaluation of student learning outcomes, and student development to actualize their potential.

Physical education teachers are human resources in the implementation of the 2013 Curriculum. The human resources used will determine the implementation and success of policies. This is in line with the opinion of Van Meter and Van Horn cited by [4] formulate six variables that influence the implementation process and appearance, namely: (1) standards and objectives; (2) resources, (3) communication between organizations; (4) the characteristics of the implementing agency; (5) social, economic and political conditions; and (6) the disposition of the executor.

In the 2013 Curriculum, the assessment is more assertive and comprehensive than the implementation of the assessment in the 2006 Curriculum. The implementation of the assessment in the 2013 Curriculum explicitly asks that teachers in schools be balanced in conducting assessments in three domains, namely cognitive, affective and psychomotor following the objectives to be measured. The emphasis on a comprehensive assessment of the three aspects provides a big change compared to the previous curriculum. Assessment has a big role in determining the success of education. A good assessment has an impact on the learning process [5] and becomes a reference for further policies [6]. The appropriateness of selecting the assessment method will greatly affect the objectivity and validity of the assessment results, which in the end is objective and valid information on the quality of education. Conversely, errors in choosing and applying assessment methods also result in invalid information regarding learning outcomes and education. Assessment in the 2013 Curriculum is considered to have more complexity than the assessment system in the previous curriculum. Although the government has prepared teachers through various training, there are still many complaints that have arisen in the field regarding assessments. The most complex in learning is the integration of learning from various domains, namely cognitive, behavior, and feelings [7].

One of the aspects that hindered the implementation of the 2013 curriculum was the complex assessment system that took a long time to compile reports. The assessment technique for the achievement of knowledge and skills is relatively not an obstacle. What is completely new is the attitude assessment, in which the majority of teachers complain about being difficult [8]. She states that one of the biggest obstacles in assessment is attitude assessment. The teacher's insight in choosing the right method and developing the assessment instrument is still lacking. Given the importance of the implementation of a good assessment in supporting the implementation of the curriculum, there is a need for a study on how to implement the assessment in the 2013 Curriculum in the field.

Assessment is an important aspect of the educational process. Assessment is a step to collect various information used for determining learning process policies [9], [10] on either a class scale or a national scale. Mardapi argues that assessment is an aspect of determining the quality of education. He suggests that the assessment should include a process of tracing, checking, searching, and concluding [6]. According to Permendiknas No. 20 of 2007, for the assessment process to run well, the assessment must be valid, objective, fair, integrated, open, comprehensive and continuous, systematic, based on criteria, and accountable. The assessment domains in the 2013 Curriculum include spiritual domains, social attitudes, knowledge, and skills. More generally, it can be categorized into three domains, namely cognitive (knowledge), affective (social and spiritual attitudes), and psychomotor (skills). 
The assessment techniques used in the learning process are (1) assessment of attitude competence through observation, self-assessment, peer assessment, and journals; (2) knowledge competency assessment through written tests, oral tests, and mastery; (3) skills competency assessment through practical tests, projects, and portfolios. The use of assessment techniques is tailored to the needs that can support the teaching program such as the basic competencies to be achieved. Careful planning, such as making instrument lattices, is expected to provide accurate information about student competencies that need to be measured, encourage students to learn to be more active in increasing their competition, motivate teaching staff to improve student competence, improve institutional performance and improve quality. education. In other words, assessment can be used to encourage improvement in the quality of learning, following what is mandated in Law Number 20 of 2003 concerning the National Education System.

Therefore, the evaluation of the implementation of educational assessments is an integral part of the Education of Standards Assessment. These minimum standards could always be improved from time to time to keep up with developments in science and technology. The implementation of the 2013 Curriculum calls for the competence of teachers in all aspects of learning, especially the competence of Physical Education teachers in assessing student learning outcomes. Almost all of the Physical Education teachers in elementary schools in Mijen District experience problems or obstacles in authentic assessment. The assessment of student learning outcomes which includes affective, cognitive, and psychomotor aspects in physical education lessons is considered by the teacher to be too complicated, making it confusing, as well as the difficulty of teachers in making assessment rubrics and processing data on assessment results for student learning outcomes reports. The problem is "How can physical education teachers in elementary schools have the understanding and skills in assessing student learning outcomes?". Thus, this Community Service focuses on training to improve the competence of physical education teachers in assessing student learning outcomes in Mijen District, Semarang City. Thus, this Community Service focuses on training to improve the competence of physical education teachers in assessing student learning outcomes in Mijen District, Semarang City.

\section{Method}

This training was an effort to improve the competence of elementary school Physical Education teachers in Mijen District, Semarang City, attended by 35 teachers. The material provided includes: 1) Definition of evaluation, tests and assessments in Physical Education, 2) Various kinds of evaluation of learning outcomes in Physical Education, 2) Assessment of alternatives in Physical Education, 3) Types/forms of tests on cognitive, affective and psychomotor aspects of tests, 4) Techniques in making assessment rubrics for the cognitive, affective and psychomotor domains. The material is presented in the form of speeches, discussions, questions, and answers, and exercises for 16 hours of meeting over 3 days. The implementation of the service program is carried out using action research steps consisting of 4 (four) stages, namely: planning, action, observation and evaluation, and reflection. Action in training is carried out with training and mentoring. The data analysis for the success of the training was carried out by comparing the data from the pre-test and post-test results, with the percentage technique, supported by qualitative data from the results of observation (observation) and evaluation. 


\section{Results and Discussion}

Competency improvement training activities for primary school physical education teachers in the assessment of student learning outcomes in Mijen District can show the suitability between the results and objectives of Community Service, namely Physical Education teachers in Mijen District have increased their ability (competence) in the assessment of student learning outcomes. This can be seen from the pre-test and post-test data, in the pre-test the average competency of physical teachers was $70 \%$ and after training/service had increased to $85 \%$, there was an increase of $15 \%$.

Table 1. Data on pre-test and post-test results

\begin{tabular}{cccc}
\hline NO & Calculation & Score & percentage \\
\hline $\mathbf{1}$ & Pre-tes & 70 & $70 \%$ \\
$\mathbf{2}$ & Post-tes & 85 & $85 \%$ \\
& Enhancement & 15 & $15 \%$ \\
\hline
\end{tabular}

This improvement is mainly in understanding the meaning of evaluation, testing, and assessment of student learning outcomes; Alternative assessment in student learning outcomes, Physical education teacher mastery in assessment techniques on cognitive, affective, psychomotor, and physical fitness aspects of students in learning, and being able to make assessment rubrics with the correct technique.

The success of this community service activity based on observation and evaluation is caused by several things as follows: 1) Physical education teachers of the elementary school in Mijen Subdistrict seriously participate in training activities, proactively in training even though during the Covid-19 Pandemic period they were still present by implementing health protocols, this can be seen in the attendance and photos of activities (attached ), teacher activities in responding to the delivery of material by the resource person; 2)This service activity is seriously monitored by the Mijen District Unit of National Education by sending the head of a working group consisting of the Principal of the SD school, to watch over the activities of the teacher in community service activities. 3) Dedication to Increase the Competence of Physical Education Teachers of Elementary School in Assessment of Learning Outcomes This student is carried out by a lecturer from the Health and Recreation Physical Education Study Program, the Faculty of Sport Sciences, Semarang State University, who has experience in evaluating, testing and assessing student learning outcomes, as well as teaching Physical Education Learning Strategies and Evaluation, Tests and Measurement of Physical Education Learning. Sports and Health. The material facilitator also delivered workshop materials for the Professional Improvement of Physical Education, Sport, Health and Recreation Study Programs both pre-service and in-service, especially in Central Java; 4) The participants of this service activity receive good guidance and assistance from the material coaches during the exercise. And the participants also received certificates that were useful for teachers in credit points for promotion, thereby increasing teacher motivation in participating in this activity.

Although this Community Service has increased the competence of elementary school physical education teachers, its competence in assessing student learning outcomes, however, there are still weaknesses or deficiencies that need to be corrected in future activities, these 
deficiencies include: 1) The participants felt that the implementation time was only 3 days with a total of 16 hours, so it needs to be added to the upcoming implementation. guidance in assessing student learning outcomes with more complete assessment examples.

\section{Conclusion}

Community service/training activities "Improvement of The Competency of Physical Education Teachers at Elementary School in Assessing Student Learning Outcomes in Mijen District" provide benefits to Physical Education Teachers, namely by increasing the ability of Physical Education teachers in assessing student learning outcomes. Besides, Physical Education teachers become more active and enthusiastic in the assessment process in learning. Training to improve competency in assessing student learning outcomes provides various assessment techniques for Physical Education teachers about the forms/techniques of assessing student learning outcomes. Through this service activity, it is hoped that it can become a reference for Physical Education teachers in the implementation of further assessment techniques.

\section{References}

[1] Imran, Pembinaan Guru di Indonesia, Jakarta: Pustaka Jaya, 2010.

[2] E. Mulyasa, Standar Kompetensi dan Sertifikasi Guru, Bandung: Rosdakarya, 2007.

[3] A. Hakim, "Contribution of Competence Teacher (Pedagogical, Personality, Profesional Competence and Social) on Performance of Learning.," International Journal of Engineering and Science, vol. 2, no. 4, pp. 1-12, 2015.

[4] J. Geldenhyus and L. Oosthuizen, "Challenges influencing teacher involvement incotinous profesional development : a South African perpective.," Teaching and TeacherEducation, vol. 51, pp. 203-212, 2015.

[5] M. Hill and P. Hupe, Implementing Public Policy, California: Sage Publication, 2009.

[6] W. Popham, Instruction that up mesures up, Virginia: ASCD, 2009.

[7] D. Mardapi, Teknik penyusunan instrumen tes dan nontes, Yogyakarta: Mitra Cendikia Press, 2008.

[8] K. Allen and B. Friedman, "Affective learning: A taxonomy for teaching social work values.," Journal of Social Work Values and Ethics, vol. 7, no. 2, 2010.

[9] Retnawati, "Hambatan Guru Matematika Sekolah Menengah Pertama dalam Menerapkan Kurikulum Baru," Cakrawala Pendidikan, vol. 34, no. 3, 2015.

[10] H. Uno and S. Koni, Assesment Pembelajaran, Jakarta: Bumi Aksara, 2012.

[11] R. L. Custer, J. Schell, B. D. McAlister, J. L. Scott and M. Hoepfl, Using Authentic Assessment in Vocational Education, Ohio: ERIC, 2000. 